\title{
The Freshwater Fish Diversity in the Sharda River at Tanakpur, Champawat District of Uttarakhand (India)
}

\author{
Hem Chandra Upadhyay ${ }^{1}$, Anupama Pandey² \\ Department of Zoology, R. H. Govt. P.G. College Kashipur, (U.K.) India
}

\begin{abstract}
Large, torrential snow-fed Sharda River in Kumaun Himalaya was studied from January 2012 to December 2012 for assessing fish diversity in the river.During entire study period 14 indigenous fish species belonging to three families (Cyprinidae, Cobitidaeand Sisoridae) were recorded in the collection. The study revealed that Cyprinidae family was dominant with 7 fish species followed byCobitidaeand Sisoridae.
\end{abstract}

Keywords: Snow-fed, Fish Diversity, Sharda River, Kumaun Himalaya

\section{Introduction}

Kumaun region of Uttarakhand state is endowed with a rich biodiversity of fishes as many rivers, streams and lakes are present in various geographical conditions. Rivers located in the Kumaun Himalaya are rich in fish diversity, though hydrological conditions of various rivers are quite distinct from that of the plains. Hill streams fishes are hyperoxic, perennial, shallow and generally characterized by low water temperature, high water velocity, turbulence and sandy rocky substratum, etc. Flow is greatly variable in time depending upon the climatic conditions and the drainage pattern in these riverine ecosystems. In the hilly areas, water current is fast and strong enough, therefore, the hill stream fishes have several unique adaptive modifications to survive successfully against these strong water currents and also other strange conditions. Sharp streamlined body shape suits their survival in high velocity currents of hilly streams and rivers. Epidermis is the outermost defensive organ which comes in direct contact with mechanical hazard caused by surrounding aquatic environment. Moreover adaptive vision in turbid water is also helpful to thrive successfully in these environments. These adaptive features together with the water quality of these ecosystems may have profound effects on the preferential distribution and diversity of the fishes, plenty of food in the form of algae, plankton, invertebrates and small fishes is available which is necessary for the growth of fishes. Today fisheries resources are at or near the point of overexploitation. Diversity of fish species provides critical information for developing conservation, management and fish production strategies.Extensive work on freshwater fish fauna and its diversity have been carried out in lentic and lotic ecosystems in India few fundamental works and comprehensive researches were carried out by Negi and Negi, 2010; Agarwal et. al, 2011; Sarkaret. al, 2011; Das et. al, 2013; Singh and Agarwal, 2013; Joshi et. al, 2014, etc.

But little published work available on fish diversity of Sharda River. Therefore the present research was carried out in order to examine the distribution, abundance and fish diversityindifferent reaches of the Sharda River in the hilly track just before debouching into the plains of Uttarakhand.
Data on the diversity of fish fauna in the snow fed river may provide important insights into a freshwater ecosystem a connecting zone between hilly and plain stretches, which may be helpful for conservation and management of the fish species.

\section{Material and Methods}

The present study was carried out in $20 \mathrm{~km}$ stretch of Sharda River at three sampling points (S1), (S2) and (S3) in Tanakpur area, Uttarakhand (Fig: 1). The study area, is located between $29^{\circ} 08^{\prime} \mathrm{N}$ latitude and $80^{\circ} 12^{\prime}$ E longitude in the foot hills of Kumaun Himalaya.Fish species were collected from all the selected spots during the entire study period with the help of local fishermen by using gill net and cast net. Immediately photographs were taken prior to preservation (10\% Formalin) since formalin decolorizes the fish color on long preservation. Fishes brought to the laboratories were fixed in this solution in separate jars according to the size of species. Identifications were carrying out by Talwar and Jhingran (1991).

\section{Results and Discussion}

Over the entire duration of the present study a total of 14 fish species belonging to 10 different genus have been recorded from the Sharda River, these species are placed under 3 different families namely Cyprinidae, Cobitidae, and Sisoridae.In the present investigation, the family cyprinidae contained maximum number of species among the other families. Similar condition was noticed in many other studies (Negi and Negi, 2010; Pathani and Upadhyay, 2011).During the whole study period Puntius ticto was present throughout the year except in the months of April, July and August at S1 and S2, and January, April, July, August, September and October at third sampling site (S3) whereasGarra gotyla was found in the months of February, March, April, June, July, October and November at S1, while in S2 this species was reported in the months of January, February, March, April, July, November and December and at third sampling site (S3) it marked the presence in the months of March, May, July, October and November. Bagarius bagarius specieswas noticed in the 


\section{International Journal of Science and Research (IJSR) \\ ISSN (Online): 2319-7064}

Index Copernicus Value (2013): 6.14 | Impact Factor (2015): 6.391

monsoon months at all the sampling sites (S1, S2 and S3).Glyptothorax pectinopterus also found only monsoon months at all three sites. Nemacheilus rupicola was reported in the months of April and September at all the sampling sites (S1, S2 and S3). Throughout the investigation period, Glyptothorax conirostris species marked its presence in monsoon months at all the sampling areas (Table 1, 2, 3). The distribution pattern of all fish species are quite variable according to environmental conditions. Seasonal variation in total number of species collected during the present investigation indicated that generally the species diversity was low during summers and monsoon months and it was high during rest of the year. Water velocity and depth are regarded as the two prime factors these are mainly responsible for the diversity and distribution of fish species in the different habitats (Negi et. al, 2007). Apart from this water velocity, high water turbidity also fluctuates the growth and distribution of fishes in some extent. The other important limiting factor that affect is geographical and thermal characteristics of the water body.

Based on the data of annual percent frequency of occurrence fish species can be categorised under five categoriesAbundant (81-100\%), Frequent (61-80\%), Common (41$60 \%)$, Occasional $(21-40 \%)$ and Rare (1-20\%).On the basis of annual percent frequency of occurrence none of the species included in abundant category. Two species namely Puntius ticto and Tor putitora were included in frequent category. In common category following fishes Garra gotyla, Labeo dyocheilus, Barilius bola, Schizothorax plagistomus and Nemacheilus botia were found. Four species, Tor tor, Botia almorhae, Botia Dario, Bagarius bagarius, Glyptothorax pectinopterus included in occasional category. Remaining two species namely Nemacheilus rupicola, Glyptothorax conirostris were foundrarely in present investigation (Table 4).

\section{Conclusion}

Overall, the present study concluded that river water was suitable for fishery development. However, the low fish species diversity in the study area may be improved by proper fishery management. Landslides, whether due to anthropogenic or natural processes can cause high water turbidity in the river, high water turbidity is not favourable for fishes. Effects of landslides can be controlled by preventing the entry of silt and garbage in the river.
Therefore, to check these things, some remedial measures should be undertaken as fishes not only have good food value but can be used for recreation.

\section{References}

[1] Agarwal N. K., Singh G. and Singh H. 2011. Present status of ichthyofaunal diversity of Garhwal Himalayan River Bhilangana and its tributaries with reference to changing environment. Environment Conservation Journal, 12 (3): 101-108.

[2] Das M. K., Sharma A. P., Vass K. K., Tyagi R. K., Suresh V. R., Naskar M. and Akolkar A. B. 2013. Fish diversity, community structure and ecological integrity of the tropical River Ganges, India. Aquat. Ecosyst. Health Manage., 16(4): 395-407.

[3] Joshi K. D., Jha D. N., Alam A., Srivastava S. K., Kumar V. and Sharma A. P. 2014. Environmental flow requirements of river Sone: impacts of low discharge on fisheries, Current science 107 (3): 478-488.

[4] Negi R. K., Joshi B. D., Negi T. and Prakash C. 2007. A study on stream morphology of some selected hill streams of district Nainital with special reference to its biotic communities. National Seminar on Limnology. (NSL '07), Jiapur, India. 288-295.

[5] Negi R. K. and Negi T. 2010. Assemblage structure of stream fishes in the Kumaon Himalaya of Uttarakhand State, India. Life Sci. J., 7 (1): 9-17.

[6] Pathani S. S. and Upadhyay K. K. 2011. An inventory of Zooplankton, Zoobenthos and Fish fauna in river RamGanga (W) of Uttaranchal, India. ENVIS Bulletin 14(2): Himalayan Ecology.

[7] Sarkar U. K., Pathak A. K., Sinha R. K., Sivakumar K., Pandian A. K., Pandey A., Debey V. K. Lakra W. S. 2011. Freshwater fish biodiversity in the river Ganga (India): changing pattern, threats and conservation perspectives, Rev. Fish. Biol. Fish., DOI: 10.1007/s11160-011-9218-6.

[8] Singh G. and Agarwal N. K. 2013. Fish diversity of Laster stream, a major tributary of river Mandakini in Central Himalaya (India) with regard to altitude and habitat specificity of fishes, J. Applied and Natural Sci., 5 (2): 369-374.

[9] Talwar P. K., Jhingran A. G. 1991. Inland Fishes of India and Adjacent Countries, (vol. 1\&2). Oxford \&IBH, New Delhi, 1158. 

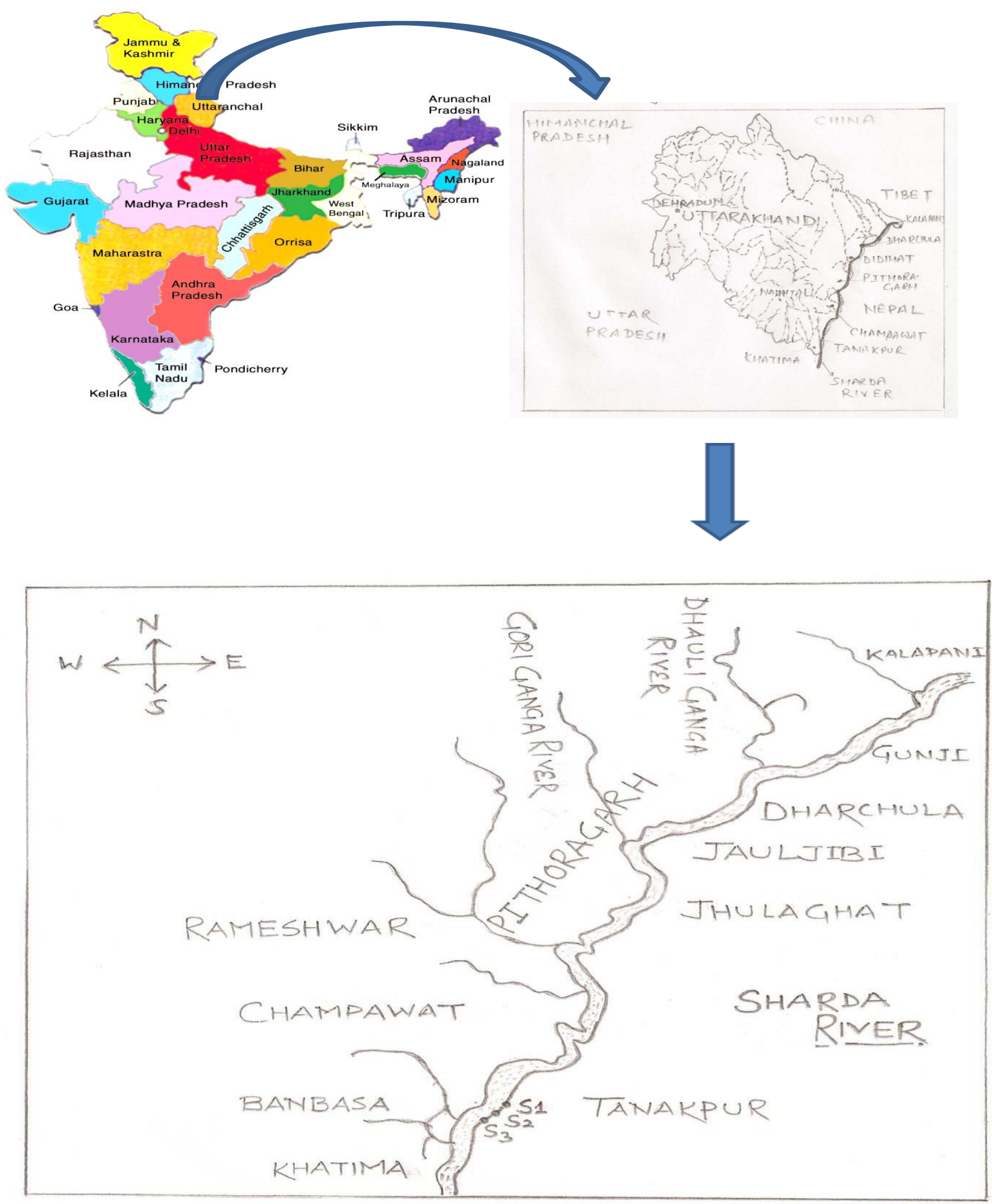

Above maps showing the river and sampling areas $\left(\mathrm{S}_{1-} 1^{\text {st }}\right.$ sampling site (Thuligad), $\mathrm{S}_{2}-2^{\text {nd }}$ sampling site (Adya Shaktipeeth-Boom temple) and $\mathrm{S}_{3}-3^{\text {rd }}$ sampling site (Hanuman Gari-Tanakpur town).

(Map is not to scale)

Figure 1

Volume 5 Issue 6, June 2016 www.ijsr.net

Licensed Under Creative Commons Attribution CC BY 


\section{International Journal of Science and Research (IJSR) ISSN (Online): 2319-7064}

Index Copernicus Value (2013): 6.14 | Impact Factor (2015): 6.391

Table 1. Qualitative composition of Ichthyofauna diversity at first sampling site (S1)

\begin{tabular}{|c|c|c|c|c|c|c|c|c|c|c|c|c|}
\hline & Jan & Feb & Mar & Apr & May & Jun & Jul & Aug & Sep & Oct & Nov & Dec \\
\hline \multicolumn{13}{|l|}{ Family Cyprinidae } \\
\hline Puntius ticto & + & + & + & - & + & + & - & - & + & + & + & + \\
\hline Garra gotyla & - & + & + & + & - & + & + & - & - & + & + & - \\
\hline Labeo dyocheilus & + & + & - & - & + & + & - & - & + & - & + & - \\
\hline Barilius bola & - & - & + & - & + & - & - & - & - & + & - & + \\
\hline Tor tor & + & - & - & - & - & - & + & - & - & - & + & + \\
\hline Tor putitora & + & + & + & + & + & + & - & + & - & + & - & + \\
\hline Schizothorax plagistomus & + & + & + & - & - & - & - & - & - & - & + & + \\
\hline \multicolumn{13}{|l|}{ Family Cobitidae- } \\
\hline Botia almorhae & + & - & - & + & - & - & - & - & - & + & + & + \\
\hline Botia dario & - & + & + & + & - & + & - & - & - & - & - & - \\
\hline Nemacheilus botia & + & + & - & - & + & - & + & - & - & + & + & - \\
\hline Nemacheilus rupicola & - & - & - & + & - & - & - & - & + & - & - & + \\
\hline \multicolumn{13}{|l|}{ Family Sisoridae } \\
\hline Bagarius bagarius & - & + & - & - & - & - & + & + & + & - & - & - \\
\hline Glyptothorax pectinopterus & + & - & - & - & - & + & + & + & - & - & - & - \\
\hline Glyptothorax conirostris & - & - & - & - & - & - & - & + & + & - & - & - \\
\hline Total & 8 & 8 & 6 & 5 & 5 & 6 & 5 & 4 & 5 & 6 & 7 & 7 \\
\hline
\end{tabular}

Table 2: Qualitative composition of Ichthyofauna diversity at second sampling site (S2)

\begin{tabular}{|c|c|c|c|c|c|c|c|c|c|c|c|c|}
\hline & Jan & Feb & Mar & Apr & May & Jun & Jul & $\overline{\text { Aug }}$ & Sep & Oct & Nov & Dec \\
\hline \multicolumn{13}{|l|}{ Family Cyprinidae } \\
\hline Puntius ticto & + & + & + & - & + & + & - & - & + & + & + & + \\
\hline Garra gotyla & + & + & + & + & - & - & + & - & - & - & + & + \\
\hline Labeo dyocheilus & + & - & + & - & + & + & - & - & + & - & + & - \\
\hline Barilius bola & - & - & + & + & - & - & - & - & - & + & + & + \\
\hline Tor tor & + & - & - & - & + & - & - & + & - & - & - & + \\
\hline Tor putitora & + & + & + & + & + & + & - & - & - & + & + & + \\
\hline Schizothorax plagistomus & + & + & - & + & - & - & - & - & + & - & + & + \\
\hline \multicolumn{13}{|l|}{ Family Cobitidae- } \\
\hline Botia almorhae & + & - & - & + & - & - & - & - & - & + & + & + \\
\hline Botia dario & - & - & + & + & - & + & + & + & - & - & - & - \\
\hline Nemacheilus botia & - & + & + & - & + & + & - & - & - & + & + & - \\
\hline Nemacheilus rupicola & - & - & - & + & - & - & - & - & + & - & - & - \\
\hline \multicolumn{13}{|l|}{ Family Sisoridae } \\
\hline Bagarius bagarius & - & + & - & - & - & - & + & + & + & - & - & - \\
\hline Glyptothorax pectinopterus & - & - & - & - & - & - & - & + & + & + & - & + \\
\hline Glyptothorax conirostris & - & - & - & - & - & - & - & + & - & - & - & - \\
\hline Total & 7 & 6 & 7 & 7 & 5 & 5 & 3 & 5 & 6 & 6 & 8 & 8 \\
\hline
\end{tabular}

Table 3: Qualitative composition of Ichthyofauna diversity at third sampling site (S3)

\begin{tabular}{|c|c|c|c|c|c|c|c|c|c|c|c|c|}
\hline & Jan & Feb & Mar & Apr & May & Jun & Jul & Aug & Sep & Oct & Nov & Dec \\
\hline \multicolumn{13}{|l|}{ Family Cyprinidae } \\
\hline Puntius ticto & - & + & + & - & + & + & - & - & - & - & + & + \\
\hline Garra gotyla & - & - & + & - & + & - & + & - & - & + & + & - \\
\hline Labeo dyocheilus & + & - & + & - & + & + & - & - & - & - & - & + \\
\hline Barilius bola & + & - & + & + & - & + & - & - & - & + & + & + \\
\hline Tor tor & + & + & - & - & + & - & - & - & - & + & - & + \\
\hline Tor putitora & + & - & + & + & - & + & - & + & + & + & + & + \\
\hline Schizothorax plagistomus & + & + & - & + & - & - & - & - & - & - & + & + \\
\hline \multicolumn{13}{|l|}{ Family Cobitidae- } \\
\hline Botia almorhae & + & - & - & + & - & - & - & - & - & + & - & + \\
\hline Botia Dario & - & + & - & + & + & + & - & - & - & - & - & - \\
\hline Nemacheilus botia & - & + & - & - & + & - & + & - & - & + & + & - \\
\hline Nemacheilus rupicola & - & - & - & + & - & - & - & - & + & - & - & - \\
\hline \multicolumn{13}{|l|}{ Family Sisoridae } \\
\hline Bagarius bagarius & - & + & - & - & - & - & - & + & + & - & + & - \\
\hline Glyptothorax pectinopterus & + & - & - & - & - & - & + & + & + & - & - & - \\
\hline Glyptothorax conirostris & - & - & - & - & - & - & + & - & - & - & - & - \\
\hline Total & 7 & 6 & 5 & 6 & 6 & 5 & 4 & 3 & 4 & 6 & 7 & 7 \\
\hline
\end{tabular}

\section{Volume 5 Issue 6, June 2016 www.ijsr.net}

Licensed Under Creative Commons Attribution CC BY 


\section{International Journal of Science and Research (IJSR) \\ ISSN (Online): 2319-7064}

Index Copernicus Value (2013): 6.14 | Impact Factor (2015): 6.391

Table 4: Percent Frequency of occurrence during entire study period in Sharda River

\begin{tabular}{|c|c|c|c|c|c|}
\hline & $\begin{array}{c}\text { Abundant } \\
(81-100 \%)\end{array}$ & $\begin{array}{l}\text { Frequent } \\
(61-80 \%) \\
\end{array}$ & $\begin{array}{l}\text { Common } \\
(41-60 \%)\end{array}$ & $\begin{array}{c}\text { Occasional } \\
(21-40 \%)\end{array}$ & $\begin{array}{c}\text { Rare } \\
(1-20 \%)\end{array}$ \\
\hline \multicolumn{6}{|l|}{ Family Cyprinidae } \\
\hline Puntius ticto & & $\sqrt{ }$ & & & \\
\hline Garra gotyla & & & $\sqrt{ }$ & & \\
\hline Labeo dyocheilus & & & $\sqrt{ }$ & & \\
\hline Barilius bola & & & $\sqrt{ }$ & & \\
\hline Tor tor & & & & $\sqrt{ }$ & \\
\hline Tor putitora & & $\sqrt{ }$ & & & \\
\hline Schizothorax plagistomus & & & $\sqrt{ }$ & & \\
\hline \multicolumn{6}{|l|}{ Family Cobitidae } \\
\hline Botia almorhae & & & & $\sqrt{ }$ & \\
\hline Botia Dario & & & & $\sqrt{ }$ & \\
\hline Nemacheilus botia & & & $\sqrt{ }$ & & \\
\hline Nemacheilus rupicola & & & & & $\sqrt{ }$ \\
\hline \multicolumn{6}{|l|}{ Family Sisoridae } \\
\hline Bagarius bagarius & & & & $\sqrt{ }$ & \\
\hline Glyptothorax pectinopterus & & & & $\sqrt{ }$ & \\
\hline Glyptothorax conirostris & & & & & $\sqrt{ }$ \\
\hline
\end{tabular}

Volume 5 Issue 6, June 2016 www.ijsr.net

Licensed Under Creative Commons Attribution CC BY 